Rev. Biol. Trop., 48(2/3): 323-331, 2000

www.ucr.ac.cr www.ots.ac.cr www.ots.duke.edu

\title{
Population dynamics and stock assessment for Octopus maya (Cephalopoda: Octopodidae) fishery in the Campeche Bank, Gulf of Mexico
}

\author{
Francisco Arreguín-Sánchez ${ }^{1}$, Manuel J. Solís -Ramírez ${ }^{2}$ and María E. González de la Rosa ${ }^{3}$ \\ 1 Centro Interdisciplinario de Ciencias Marinas del IPN, CICIMAR. Apartado Postal 592, 23000, La Paz, Baja \\ California Sur, México. Fax: +52 (1) 12253 22. E-mail: farregui@redipn.ipn.mx, farregui@ hotmail.com \\ 2 Centro Regional de Investigación Pesquera de Yucalpetén, INP. Apartado Postal 73, 97320 Progreso, Yucatán, México \\ 3 Centro Regional de Investigación Pesquera de Lerma, INP. Apartado Postal 140, 25400, Campeche, Campeche, \\ México.
}

Received 22-II-1999. Corrected 7-XII-1999. Accepted 13-XII-1999.

\begin{abstract}
The octopus (Octopus maya) is one of the most important fish resources in the Mexican Gulf of Mexico with a mean annual yield of 9000 ton, and a reasonable number of jobs created; $O$. maya represents $80 \%$ of the total octopus catch, followed by Octopus vulgaris. There are two artisanal fleets based on Octopus maya and a middle-size fleet that covers both species. Catch-at-length structured data from the artisanal fleets, for the 1994 season (August $1^{\text {st }}$ to December $15^{\text {th }}$ ) were used to analyze the $O$. maya population dynamics and stock and to estimate the current level of exploitation. Von Bertalanffy growth parameters were: $\mathrm{L} \infty=252 \mathrm{~mm}$, mantle length; $\mathrm{K}=1.4$ year $^{-1}$; oscillation parameters $\mathrm{C}=1.0, \mathrm{WP}=0.6$; and $\mathrm{tz}=0.842$ years. A rough estimate of natural mortality was $M=2.2$, total mortality from catch curve $Z=8.77$, and exploitation rate $F / Z=0.75$. This last value suggests an intensive exploitation, even when yield per recruit analysis indicates both fleets may increase the minimum legal size on about $10 \%$ to increase yields. The length-based VPA also shows that the stock is being exploited under its maximum acceptable biological limit. These apparently contradictory results are explained by biological and behavioral characteristics of this species. Because most females die after reproduction, a new gross estimation of natural mortality was computed as $M=3.3$. The new estimate of exploitation rate was $\mathrm{F} / \mathrm{Z}=0.57$. This new value coincides with results from the length-VPA and the Thompson and Bell methods, the former suggesting that a reduction of $20 \%$ in fishing mortality may provide larger yields. This fishery resource is fully exploited and current management measures must be revised to sustain and probably optimize yields.
\end{abstract}

Key words: Octopus, Octopus maya, stock assessment, Gulf of Mexico, length frequency data analysis

The octopus fishery in the north continental shelf of Yucatan is supported by two species; the endemic Octopus maya Voss and Solís, 1966, which makes up to $80 \%$ of the total catch, and the cosmopolitan Octopus vulgaris, Cuvier, 1797. Three fleets participate in this fishery, two artisanal operating in shallow waters, and a middle-sized-boats fleet fishing in deeper waters. The fishing gear, locally named "jimba", consists of a rod with several lines having live crabs as bait. Boats drift along, and when the bait gets close to the octopus, it catches the crab and then fishermen capture it. All fleets independently of the size of boats carry out this operation. Thus the size of the boats has no effect on the fishing power, except for the numbers of rods per boat, and the size of octopus which increases with depth (Solís-Ramírez 1967, 1988, 1990; SolísRamírez and Chávez 1986; Arreguín-Sánchez et al. 1987; Solís-Ramírez et al. 1999). The artisanal fleets catch about $80 \%$ of the total 
annual yield exclusively on $O$. maya. The species composition of the middle-sized fleet is as follows: $O$. vulgaris between $20 \%$ to $30 \%$ of the total catch, and $O$. maya making difference.

- From the biological point of view, $O$. maya exhibits important differences with other species. There are not planktonic larvae; females deposit eggs inside caves, and care for them. After seven to nine weeks, eclosion occurs and new individuals appear as juvenile octopuses, becoming almost immediately active predators. During the month of hatching, females are unavailable for fishing, starve and die after eclosion. This reproductive behavior increases the natural mortality during reproduction, and restricts diving as fishing technique, because there is no control on mortality of mature females, with a high risk of eggs mortality (Solís-Ramírez 1967; SolísRamírez et al. 1999). O. maya life expectancy has been estimated in 18 months (SolísRamírez 1967; Solís-Ramírez and Chávez 1986; Solís-Ramírez et al. 1999).

Fishing season starts on August $1^{\text {st }}$, when a reproductive aggregation occurs in shallow waters, synchronized with the time of the year of maximum runoff into the continental shelf. The fishing season remains opened until December $15^{\text {th }}$. Annual yields in the last decade range from $7000 \mathrm{t}$ to $12000 \mathrm{t}$, averaging $9000 \mathrm{t}$ per year (Fig. 1). Another management measure is a minimum legal size of $11 \mathrm{~cm}$ in mantle length, ML, (approximately 3 individuals per kilogram, kg). ArreguínSánchez (1992a) mentioned that during the August aggregation the average age is 5-6 months old, meaning that these individuals come from an earlier reproductive aggregation occurring period during off season which probably is synchronized with the seasonal upwelling of April-May. These features are important for management purposes, however, until now, they have not being quantified in terms of the population dynamics.

Most short lived species present a high variation in population biological processes being also the case for $O$. maya. ArreguínSánchez (1992b) shows the effect on growth of an inter-annual recruitment pattern. When recruitment peaks late in the year (SeptemberOctober), growth curves exhibit an oscillatory pattern during the next year, but when recruitment peaks early in the year (June), growth oscillations are not observed.

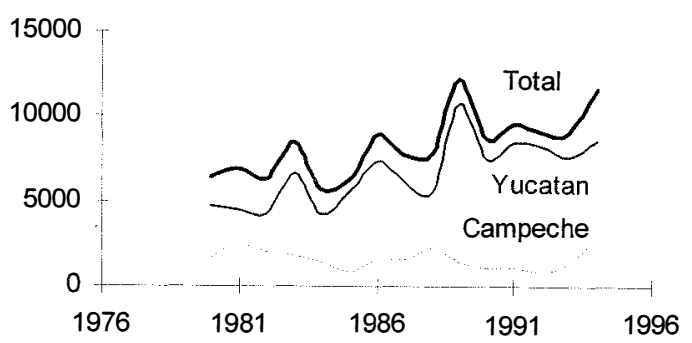

Fig. 1. Historical tendency of the annual yields (tonnes) for octopus fishery from the Campeche Bank, Mexico.

On the other hand, some studies indicated the convenience of a moving closure period, or to reduce duration of the fishing season. In the first case, some authors suggest fishing season must start before current date while others recommend closure must start some time later (Arreguín-Sánchez 1989; Seijo et al. 1987). These apparent contradictory results were based on data from different fishing seasons; the strong inter-annual variation in the seasonal recruitment patterns shown by ArreguínSánchez (1992b) may explain these differences. Their implications to management are obvious.

The aim of this paper is to make a detailed analysis of the population dynamics and stock assessment, for the particular case of the 1994fishing season.

\section{MATERIALS AND METHODS}

O. maya samples were taken with a frequency of two weeks from landing ports located along the north and western coast of the Yucatan Peninsula (Fig. 2). Sampling frequency was two weeks, using a basic random design to select both, boats within each location, and numbers of specimens caught within each boat. Information from each sample was used to estimate catch structure of the boat and to the 
total catch for each location in the two-week period. Because ports were not simultaneously sampled, catch structure was expressed on a monthly basis as catch-at-length data. Due to different fishing strategies, samples from each fleet were analyzed separately. In Campeche there is only an artisanal fleet which operates in shallow waters ( 3 to $15 \mathrm{~m}$ deep) on a single-boat basis; while in Yucatan there are two fleets; one operating in relatively deeper waters $(30 \mathrm{~m})$, and an artisanal fleet (27 feet boats), which operates in shallow waters, frequently under a nurse-boat which gives more autonomy to the fishing operations. The artisanal fleet of Yucatan also fishes in deeper waters than the artisanal fleet from Campeche.

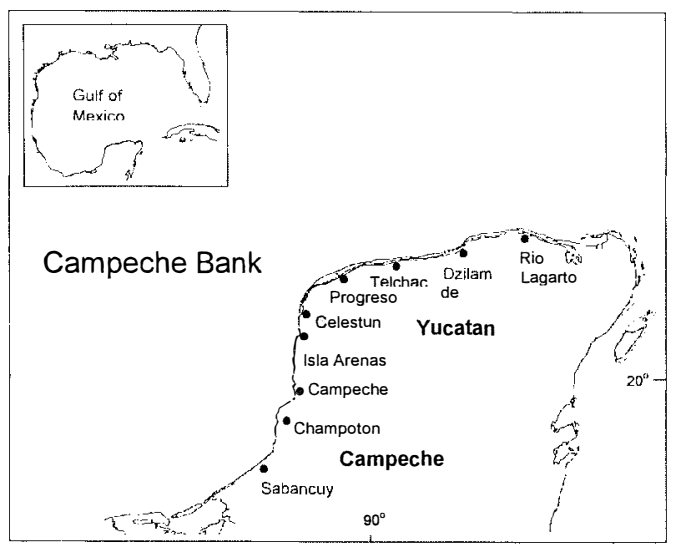

Fig. 2. Main landings ports of octopus catches along the coasts of Campeche and Yucatan states, which were used as sampled sites.

Based on the monthly catch-at-length data per fleet, an analysis of the population dynamics was performed, assuming that octopuses grow according to the von Bertalanffy equation, VBGE, incorporating growth oscillations (Arreguín-Sánchez 1992b, Pauly 1982, 1987).

Parameters of the VBGE were estimated using the ELEFAN I method (Pauly 1987) as provided in the FiSAT software (Gayanilo et al. 1994). ELEFAN I uses an algorithm to maximize the function $\mathrm{Rn}$, which can be interpreted as a correlation coefficient. A first approach to the asymptotic length, $L \infty$, was obtained with the Wetherall (1986) plot. Taken this value of $L_{\infty}$ as a seed fixed value an approximate value of $\mathrm{K}$ was obtained by scanning $\mathrm{K}$ over a wide range of values. These initial values for $L \infty$ and $K$ were then fixed, and seasonal oscillation parameters $\mathrm{C}$ and WP estimated using the surface response routine. For all cases $\mathrm{Rn}$ was used as criteria for decision. These new parameters ( $\mathrm{C}$ and WP) and $L \infty w e r e$ now fixed and a new $\mathrm{K}$ value was scanned. These processes were iteratively continued until no changes were detected. In a last step, the automatic search routine was used, with all parameters varying within small ranges to obtain the final values of the VBGE.

Selection by the fishing gear was assumed to follow a sigmoidal probability curve in attention to the ability of octopus to catch preys over a wide range of sizes, and because octopus below legal size are returned to the sea. This assumed pattern, although similar for the fleets, may show some differences due to differences in practices fishing, depth, fishing grounds, and availability of octopuses. To overcome these, a selection pattern was estimated for each fleet through a backward estimation of the slope of the catch curve (Pauly 1982). Catch curves also provided a preliminary estimation of the instantaneous rate of total mortality, which was compared with that from Jones and vanZalinge method (1981).

For natural mortality no independent estimates were made. Following previous studies (Solís-Ramírez and Chávez 1986) two methods were applied, Rikhter and Efanov (1976) using t mass (the age at which 50\% of females reach the age of "massive spawning") as six months (Solís Ramírez 1967); and Pauly (1980) equation with an average temperature of the stock habitat, $\mathrm{T}=25^{\circ} \mathrm{C}$.

With the estimation of natural mortality and probabilities of selection, a yield per recruit analysis (Beverton and Holt 1957) was performed, for each fleet.

Fishing mortality at length was estimated for each individual fleet following Jones $(1981,1984)$. As a first step, an arbitrary value of fishing mortality for largest length-class was 
used to estimate fishing mortality-at-length $\left(\mathrm{F}_{\mathrm{i}}\right)$ and the stock size $\left(\mathrm{N}_{\mathrm{i}}\right)$. With these values an estimated catch $\left(\hat{\mathrm{C}}_{\mathrm{i}}\right)$ per length-class was obtained. The best fit for $\mathrm{Fi}$ and $\mathrm{Ni}$ were then obtained by using a single least squares algorithm taken al goal function the minimization of the sum of $\left(\mathrm{C}_{\mathrm{i}}-\hat{\mathrm{C}}_{\mathrm{i}}\right)^{2}$ over all length classes.

For the analysis of the current state of exploitation and forecast, the Thompson and Bell (1934) method was applied to the whole fishery by adding the contribution of each individual fleet to total fishing mortality, and for the whole stock, the catch in numbers and weight, per size and fleet were also added.

\section{RESULTS}

Growth and natural mortality: Von Bertalanffy growth parameters were as follows: $\mathrm{L} \infty=252 \mathrm{~mm} \mathrm{ML}, \mathrm{K}=1.4$ year $^{-1}$; $\mathrm{C}=1.0, \mathrm{WP}=0.6$ and $\mathrm{tz}=0.842$ years (Fig. 3 ). These values are in close agreement with those estimated by Arreguín-Sánchez (1992b), Arreguín-Sánchez et al. (1994) and SolísRamírez et al. (1991) (Fig. 4).

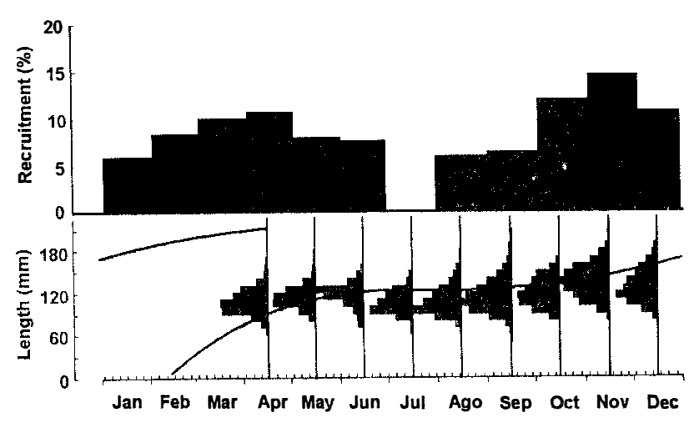

Fig. 3. Mantle lenght $(\mathrm{mm})$ growth curve for Octopus maya in the campeche Bank as estimated with ELEGFAN I method (down), showing on the upper side the two peaks recruitment pattern (percent).

Total mortality from the catch curve and for the Jones and vanZalinge methods were $\mathrm{Z}=8.77$ and $\mathrm{Z}=6.6$, respectively. From backward computation of catch curves, selection patterns were estimated for each fleet. The value of $\mathrm{L} 50 \%$ for the Campeche fleet was $\mathrm{L} 50 \%=97.2 \mathrm{~mm} \mathrm{ML}$, with a range of selection (L 75\%-L 25\%), rs $=17.9 \mathrm{~mm}$; while the Yucatan fleet L50\% $=100.7 \mathrm{~mm}$ ML and $\mathrm{rs}=17.0 \mathrm{~mm}$. These values indicate differences between fleets.

The instantaneous rate of natural mortality estimated from the Rikhter and Efanov (1976) equation was $M=2.35$, with age of massive spawning as 6 months old (Solís-Ramírez 1967), and $M=2.2$, after Pauly (1980), with a mean annual temperature of $25^{\circ} \mathrm{C}$. For further analysis $\mathrm{M}=2.2$ was used. For exploitation rate, a rough analysis of the catch curve gives a high total mortality rate of $\mathrm{Z}=8.76$ for both fleets, and an exploitation rate of $F / Z=0.75$, suggesting a very intensive exploitation.

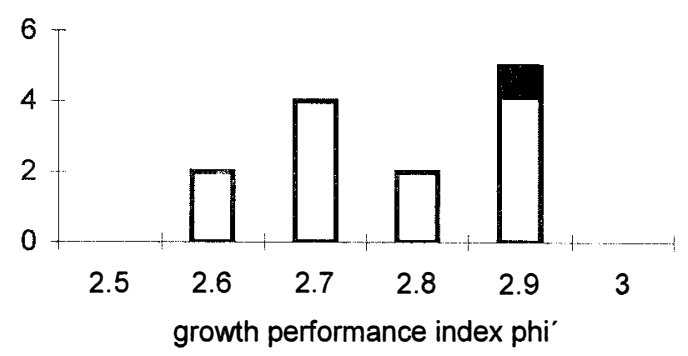

Fig. 4. Frequency distribution (number of cases) of the growth performance index $\phi^{\prime}$ (X axis) for Octopus maya from the Campeche Bank, Mexico. Black area indicates estimation from this contribution, others are from literature.

Yield per recruit analysis. Although selection patterns indicate that the length-atfirst catch, L50\%, is slightly lower for Campeche than Yucatan fleet, yield per recruit shows that both fleets may increase the minimum legal size by about $10 \%$ to obtain the maximum (biological) yields (Fig. 5). Table 1 shows the statistics on yield per recruit suggesting that the fishery is operating close to the maximum levels of biological production, but with exploitation rates higher than those required to maximize yield per recruit. 
TABLE 1

Estimated parameters of the yield per recruit analysis for the Octopus maya fishery from the Campeche Bank, Mexico.

Parameter Campeche fleet Yucatan fleet

\section{Current Lc}

$\mathrm{E}$ at $\max \mathrm{Y} / \mathrm{R}$

at 0.1 of origin slope

0.504

0.318

0.535

0.507

$\mathrm{E}$ at 0.5 of $\mathrm{B} / \mathrm{R}$

0.318

Isopleth diagram analysis

$\begin{array}{lll}\text { L50 / L } \infty \text { (actual) } & 0.386 & 0.400 \\ \text { L50 / L } \infty \text { (optimum) } & 0.450 & 0.450\end{array}$

Optimum level of Lc and $\mathrm{E}$

$\mathrm{E}$ at $\max \mathrm{Y} / \mathrm{R}$

0.550

$\mathrm{E}$ at 0.5 of $\mathrm{B} / \mathrm{R}$

0.383

$\mathrm{E}$ at 0.1 of origin slope

0.495

0.550

0.377

0.486

Current Lc and optimum E

$\mathrm{E}$ at $\max \mathrm{Y} / \mathrm{R}$

0.500

$\mathrm{E}$ at 0.5 of $\mathrm{B} / \mathrm{R}$

0.393

$\mathrm{E}$ at 0.1 of origin slope

0.419

0.550

0.386

0.504

Data according with the Beverton and Holt (1957) model, and for each individual fleet. $\mathrm{E}=$ exploitation rate. $\mathrm{Y} / \mathrm{R}=$ yield per recruit; $\mathrm{B} / \mathrm{R}=$ biomass per recruit; $\mathrm{E}$ at 0.1 refers to marginal yield according with Gulland and Boerema (1971)

Despite differences between the artisanal fleets, yield per recruit analysis indicates that both fleets operated under a similar scheme of exploitation, being selection of larger individuals slightly higher for the Yucatan fleet.

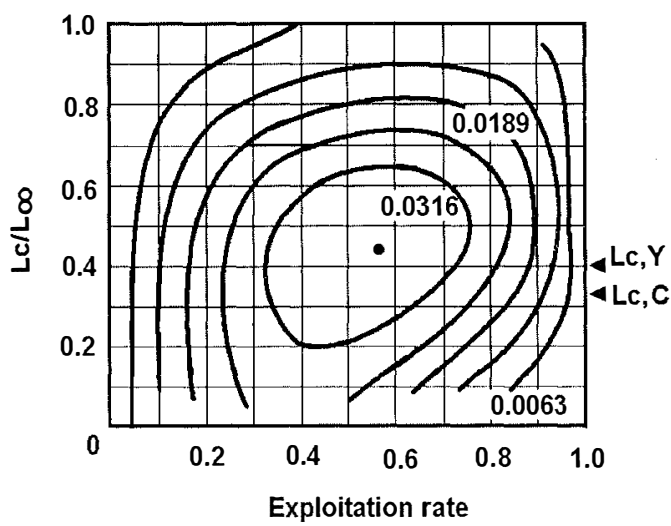

Fig. 5. Yield per recruit isopleths (g) for Octopus maya from the Campeche Bank. Black dot indicates maximum yield-per-recruit ( $\mathrm{Y}$ axis, as $\mathrm{Lc} / \mathrm{L} \infty$ ) for the whole fishery, as a function of exploitation rate (X axis). $\mathrm{Lc}, \mathrm{Y}$ and $\mathrm{Lc}, \mathrm{C}$ represent the length at first capture for the Yucatan and Campeche fleets, respectively.
Length-based VPA. In general, fishing mortality with length tend to increase, showing higher values for larger individuals, usually $F_{i}>3.0$ (Fig. 6). This behavior shows $F_{i}$ increases with size, and relative high values for $\mathrm{Fi}$ as expected for full exploited short-lived species. As in the catch curve, these estimates suggest high levels of exploitation. Specific values for fishing mortality-at-length and the average population size per fleet, are in Table 2. Comparison of fishing patterns between fleets (Fig. 6) indicates higher mortalities on small individuals by the Campeche fleet. This effect is a consequence of differences in fishing strategies.

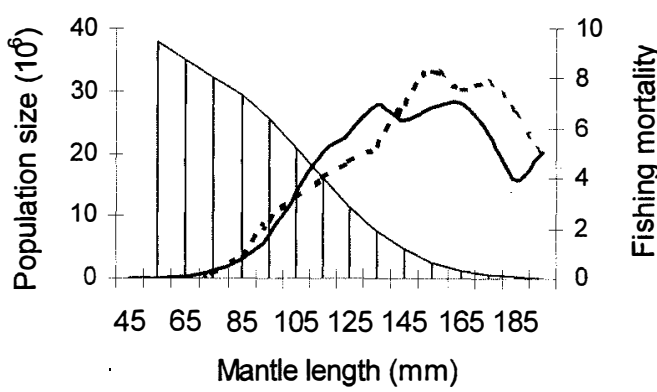

Fig. 6. Fishing mortality-at-mantle length (Y axis on right) tendency as estimated from the lenght-VPA for the Octopus maya fishery from the Campeche Bank. Droplines indicate population size ( $\mathrm{Y}$ axis on left, in millions) as a function of mantle length classes ( $\mathrm{X}$ axis); dashed and bold lines the fishing pattern for the Yucatan and campeche fleets, respectively.

Thompson and Bell analysis. Using estimates of the fishing mortality and population size per fleet from length-VPA, the Thompson and Bell method was applied to obtain a diagnosis of the state of exploitation over the whole fishery. Results (Table 3) suggest that current fishing effort level could be reduced by a factor of 0.76 for the fleet of Yucatan, and 0.79 for the Campeche fleet to maximize yields (Fig. 7). These results also suggest that current fishing intensity overpasses the level which maximize yields and yield-per-recruit.

Recruitment pattern. The FiSAT routine to estimate recruitment pattern reconstructs recruitment pulses from a time series of length- 
frequency data to determine the number of pulses per year and the relative strength of each pulse. Computation consisted of the backward projection of the frequencies, along a trajectory defined by the VBGE onto the time axis of a time-series of samples. Results generated by this routine should be treated as approximations because, while allowing statements on the number of annual pulses and on their relative strength, this model is based on two assumptions that are rarely met in reality: 1) all individuals in the sample grow as described by a single set of growth parameters and, 2) one month out of twelve always has zero recruitment.

This approach was applied to O. maya once the information of both fleets was combined. Two peaks of approximately the same size were observed, one in October, and the second in April (Fig. 3). The first peak coincides with observations during the fishing season, as mentioned by several authors (Solís-Ramírez 1967, 1990; ArreguínSánchez 1992b; Solís-Ramírez et al. 1999). The second peak, in April, has not been observed because it occurs off-season, but agrees with Arreguín-Sánchez`s (1992a) hypothesis on a second reproductive period providing individuals recruits to the fishing season. This also agrees with the pattern suggested by Arreguín-Sánchez y Chávez (1999) in the sense that octopus dynamics is related with pulses of primary production induced by nutrient exports from Laguna de Términos during autumn, and seasonal upwelling during spring.

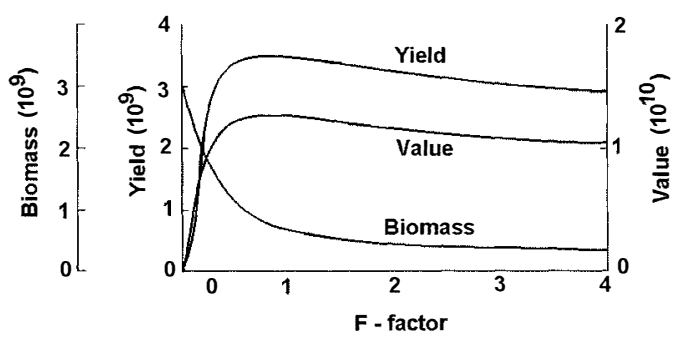

Fig. 7. Yields $\left(10^{3}\right.$ tonnes, on top) and biomass $\left(10^{3}\right.$ tonnes, down) estimates for a range of Factors (fishing mortality factors on $\mathrm{X}$ axis) for the octopus (Octopus maya) fishery in the Campeche Bank. Mexico, according with the Thompson and Bell method.

TABLE 2

Parameters for the artisanal octopus fishery in the Campeche Bank, Mexico.

$\begin{array}{ccccccc}\text { Length } & \mathrm{F}_{\mathrm{i}} \text {-Cam. } & \mathrm{N}_{\mathrm{i}} \text {-Cam } & \mathrm{Y}_{\mathrm{i}} \text {-Cam } & \mathrm{F}_{\mathrm{i}} \text {-Yuc } & \mathrm{N}_{\mathrm{i}} \text {-Yuc } & \mathrm{Y}_{\mathrm{i}} \text {-Yuc } \\ 45 & 0.000 & 9471.1 & 0.00 & & & \\ 55 & 0.025 & 8778.6 & 0.60 & & & 29136.5 \\ 65 & 0.049 & 8098.2 & 1.77 & 0.023 & 26897.5 & 0.39 \\ 75 & 0.305 & 7431.4 & 15.22 & 0.138 & 24707.2 & 23.05 \\ 85 & 0.750 & 6716.8 & 48.47 & 0.964 & 22481.7 & 207.59 \\ 95 & 1.752 & 5920.3 & 136.65 & 2.336 & 19635.4 & 596.67 \\ 105 & 3.451 & 4945.8 & 294.94 & 3.243 & 15972.8 & 899.36 \\ 115 & 5.014 & 3757.8 & 418.26 & 4.042 & 12259.7 & 1126.72 \\ 125 & 5.836 & 2579.4 & 428.99 & 4.619 & 8852.7 & 1203.01 \\ 135 & 6.922 & 1641.0 & 406.18 & 5.391 & 6031.4 & 1213.50 \\ 145 & 6.317 & 940.0 & 276.30 & 7.023 & 3793.4 & 1213.58 \\ 155 & 6.871 & 532.1 & 212.17 & 8.257 & 2048.5 & 938.47 \\ 165 & 6.993 & 272.7 & 138.94 & 7.577 & 947.8 & 512.42 \\ 175 & 5.769 & 128.1 & 71.00 & 7.816 & 424.3 & 293.59 \\ 185 & 3.976 & 61.1 & 31.98 & 6.515 & 167.3 & 127.56 \\ 195 & 5.047 & 31.6 & 42.26 & 4.900 & 65.9 & 87.45\end{array}$

Fishing mortality-at-length $\left(\mathrm{F}_{\mathrm{i}}\right)$, population size $\left(\mathrm{N}_{\mathrm{i}} \cdot 10^{3}\right)$ and yield $\left(\mathrm{Y}_{\mathrm{i}}\right.$, in ton) per fleet (Cam=Campeche, Yuc=Yucatan). Length refers to mantle length in mm. (following Jones, 1981, 1984). 
TABLE 3

Long term forecast for the Octopus maya fishery of the Campeche Bank, Southern Gulf of Mexico.

$\begin{array}{cccccc}\begin{array}{c}\text { Mantle length } \\ (\mathrm{mm})\end{array} & \begin{array}{c}\text { Number at } \\ \text { the sea } 10^{5}\end{array} & \begin{array}{c}\text { Mean } \\ \text { biomass ton }\end{array} & \begin{array}{c}\text { Catch } \\ 10^{3}\end{array} & \begin{array}{c}\text { Yield } \\ \text { ton }\end{array} & \begin{array}{c}\text { Fishing } \\ \text { mortality 1/year }\end{array} \\ 40 & 409.0 & 67.3 & 0.0 & 0.0 & 0.000 \\ 50 & 379.1 & 107.5 & 8.7 & 0.7 & 0.007 \\ 60 & 350.0 & 157.9 & 27.1 & 3.3 & 0.021 \\ 70 & 321.5 & 217.9 & 159.1 & 28.0 & 0.128 \\ 80 & 292.7 & 283.3 & 786.4 & 189.1 & 0.667 \\ 90 & 258.9 & 343.6 & 1737.7 & 551.6 & 1.605 \\ 100 & 217.7 & 387.1 & 2281.7 & 930.3 & 2.403 \\ 110 & 174.0 & 406.8 & 2474.4 & 1266.7 & 3.114 \\ 120 & 131.7 & 400.8 & 2266.9 & 1429.8 & 3.568 \\ 130 & 95.1 & 370.2 & 2016.4 & 1542.1 & 4.166 \\ 140 & 64.3 & 314.4 & 1726.7 & 1579.5 & 5.023 \\ 150 & 39.4 & 240.7 & 1293.9 & 1398.9 & 5.812 \\ 160 & 21.6 & 169.3 & 728.2 & 920.8 & 5.438 \\ 170 & 11.4 & 113.4 & 413.4 & 605.9 & 5.340 \\ 180 & 5.6 & 73.4 & 183.9 & 309.7 & 4.221 \\ 190 & 2.7 & 47.8 & 90.8 & 174.6 & 3.650 \\ 210 & 0.5 & 10.2 & 32.1 & 37.1 & 3.650\end{array}$

The Thompson and Bell (1934) method was applied as implemented in FiSAT (Gayanilo et al. 1994). Estimations are for the whole fishery (Campeche and Yucatan fleets) at the maximum yield level, corresponding to a fishing mortality factor of 0.73 respect to that for 1994 fishing season.

\section{DISCUSSION}

Estimates of growth performance index $\phi^{\prime}$ (Pauly and Munro 1984) are in agreement with those from other authors (Arreguín-Sánchez 1992b; Arreguín-Sánchez et al. 1994; and SolísRamírez et al. 1991); although they are among the highest values (Fig. 4). This probably is because previous estimations were based on length distributions of the Yucatan fleet, where small sizes are poorly represented. In this paper small sizes from the Campeche fleet were included. The effect of small sizes in the analysis of the length composition data using ELEFAN I, has been discussed by Defeo et al. (1992).

Estimates of exploitation rate show heavy exploitation. Different authors (ArreguínSánchez et al. 1987, 1994; Seijo et al. 1987; Arreguín-Sánchez 1992a; Solís-Ramírez et al. 1999) have established that it is fully exploited; however heavy exploitation, as indicated here by exploitation rates, and full exploitation have not the same meaning. Full exploitation indicates that the stock is being used at its maximum biological capacity of biomass production, while heavily exploitation suggests the above level have been exceeded.

From VPA analysis it is clear that larger individuals experience higher mortalities; however interpretation of these values must be associated with population behavior, particularly, female behavior. It was mentioned before those most gravid females of $O$. maya die after their egg hatch. Because the methods used to estimate total mortality account for a decrease in numbers, and because natural mortality is assumed to be constant, and computed by independent rough methods, posthatching females mortality is computed here within the fishing mortality rates; this implies exploitation rates may give higher values. The main problem is the lack of information on posthatching mortality of females to adjust fishing mortality computations. 
Sex ratio has been reported by SolísRamírez (1967) as 1: 1. Since all females die after hatching, natural mortality should increase in the same proportion that the stock decreases. An artificial value of $\mathrm{M}=3.3$ may be used (reducing fishing mortality in the same proportion as $\mathrm{M}$ increases) to obtain an adjusted exploitation rate. This renders an exploitation rate $\mathrm{E}=\mathrm{F} / \mathrm{Z}=0.57$, which is closer to the concept of full exploitation and to those estimates for maximum exploitation levels from the yield per recruit analysis. This value of $\mathrm{E}=0.57$ resulted of a rough approach to how post-hatching mortality could affect estimates of exploitation rate. Computations above, although reasonable, are not documented by experimental data.

The conclusion is that $O$. maya, during the 1994 fishing season was fully exploited. Estimates suggest that fishing mortality must be controlled, but in the absence of a year-toyear analysis, it is not possible to recommend specific measures. In terms of management, it can only be recommended that no more fishing licenses should be given, maintain current management measures, and increase scientific efforts to obtain information to adjust computations of fishing mortality due to posthatching female mortality.

Although it is not formally discussed due to the lack of data, recruitment pattern as estimated by FiSAT indicates two peaks of reproduction which agrees with the current hypothesis about dynamics of $O$. maya stock. If evidences were confirmed, it would have consequences in management strategies regarding controls by fishing mortality. We strongly recommend intensive research on this subject.

\section{ACKNOWLEDGMENTS}

The authors thank Luis Capurro and two anonymous referees for their valuable comments. The first author also thanks Instituto Politécnico Nacional for support given through COFAA, EDD, and DEPI980056.

\section{RESUMEN}

Octopus maya es uno de los recursos pesqueros más importantes del Golfo de México, con rendimientos anuales promedio de $9000 \mathrm{t}$, y constituye el $80 \%$ de la captura total, seguido por $O$. vulgaris. En la pesquería participan dos flotas artesanales sobre $O$. maya, y una de mediana altura capturando ambas especies. Datos de frecuencia de longitudes de la captura para la temporada de pesca 1994 (Agosto $1^{\circ}$ a Diciembre 15) fueron usados para analizar la dinámica poblacional y el estado de explotación de O. maya. Los parámetros del modelo de von Bertalanffy fueron: $\mathrm{L}^{0}=252 \mathrm{~mm}$ longitud de manto, $\mathrm{K}=1.4 \mathrm{años}^{-1}$, $\mathrm{C}=1.0$ y WP $=0.6$, y $\mathrm{z}=0.842$ años. Una estimación inicial de la mortalidad natural fue $\mathrm{M}=2.2$, la mortalidad total $\mathrm{Z}=8.77$, y tasa de explotación $\mathrm{F} / \mathrm{Z}=0.75$, lo cual sugiere una intensa explotación. El análisis de rendimiento por recluta indica que podría aumentarse la talla mínima legal para incrementar los rendimientos. El VPA indica un recurso explotado al límite de su capacidad biológica. Debido a que las hembras mueren después de la reproducción, una nueva estimación de mortalidad natural, $M=3.3$, y tasa de explotación, $F / Z=0.57$ fueron obtenidas, coincidiendo con los resultados del VPA basado en longitudes y el método de Thompson y Bell

\section{REFERENCES}

Arreguín-Sánchez, F. 1989. Population of tropical fisheries: the Mexican experience, p. 241-256. In E.A. Chávez (ed.). Proc. Workshop AustraliaMexico on Marine Science. Centro de Investigación y Estudios Avanzados IPN, Unidad Mérida. México.

Arreguín-Sánchez, F. 1992a. Consideraciones sobre el manejo de la pesquería del pulpo Octopus maya en el Banco de Campeche, Mexico. Jaina 3: 18.

Arreguín-Sánchez, F. 1992b. Growth and seasonal recruitment of the Octopus maya from de Campeche Bank caught by the artisanal fleet. NAGA ICLARM Q.15: 31-34.

Arreguín-Sánchez, F. \& E.A. Chávez. 1999. How marine shelf fisheries are depending of mangrove ecosystems: the Campeche Bank, Mexico, as an example. In: Yáñez-Arancibia, A. \& A.L. LaraDomínguez (eds.). Valoración económica de los manglares. Univ. Autón. Campeche. EPOMEX Serie Científica 6. México. (in press).

Arreguín-Sánchez, F., J.C. Seijo, D. Fuentes \& M.J. SolísRamírez. 1987. Estado del conocimiento de los recursos pesqueros de la plataforma continental de Yucatán y región adyacente. CRIP-Yucalpetén, INP. Contr. Inv. Pesq. Doc. Tec. 4. México. 41p. 
Arreguín-Sánchez, F., M.J. Solís-Ramírez, J.A. Sánchez, E. Valero \& M.E. González de la Rosa. 1991. Age and growth study of the octopus (Octopus maya) from the continental shelf of Yucatan, Mexico. proc. 44th Ann. Sess. Gulf and Caribbean Fisheries Institute.

Beverton, R.J.H. \& S.J. Holt. 1957. On the dynamics of exploited fish populations. Fish. Invest. Ser. II. 19: 533p.

Defeo, O., F. Arreguín-Sánchez \& J.A. Sánchez. 1992. Growth study of the yellow clam Mesodesma mactroides: a comparative analysis of three lengthbased methods. Scientia Marina. 56: 53-59

Gayanilo, F.C., P. Sparre \& D. Pauly. 1994. The FAOICLARM Stock Assessment Tools (FiSAT) User's guide. FAO Computarized Series. Fisheries No. 6. Rome. 186p.

Gulland, J. A. \& L.K. Borema. 1983. Scientific advice on catch levels. Fish Bull.(US) 71: 325-335.

Jones, R. 1981. The use of lenght composition data in fish stock assessments (with notes on VPA and cohort analysis). FAO Fish. Circ. 734. Roma. 55p.

Jones, R. 1984. Assessing the effects of changes in exploitation pattern using length composition data (with notes on VPA and cohort analysis). FAO. Fish. Tec. Pap. 256. Roma. 118p.

Jones, R. \& N.P. van Zalinge. 1981. Estimations of mortality rate and population size for shrimp in Kuwait waters. Kuwait Bull. Mar, Sci. 2: 273-288.

Pauly, D. 1980. On the interrelationship between natural mortality, growth parameters and mean environmental temperature in 175 fish stocks. J. Cons. Int. Explor. Mer. 39: 175-192.

Pauly, D. 1982. Studying single species dynamics in tropical multi-species context. In Pauly, D. \& R.G. Murphy (eds.). Theory and management of tropical fisheries. ICLARM Conf. Proc. 9: 33-70

Pauly, D. 1987. A review of the ELEFAN system for analysis of length.frequency data in fish and aquatic invertebrates. p. 7-34. In D. Pauly \& G.P. Morgan (eds.). Length-based methods in fisheries research. ICLARM Conf. Proc. 13. Philippines

Pauly, D. \& J.L. Munro. 1984. Once more on the comparison of growth in fish and invertebrates. Fishbyte 2: 21

Rikhter, V.A. \& V.N. Efanov. 1976. On one of the approaches to estimation of natural mortality of fish populations. ICNAF 9: 65-74.
Seijo, J.C., M.J. Solís-Ramírez \& G. Morales. 1987. Simulación bioeconómica de la pesquería de pulpo Octopus maya de la plataforma continental de Yucatán. p. 125-138. In M. Ramírez (ed.). Mem..Simp. Inves. Biol. Ocean. Pesq. México. La Paz, B.C.S. México.

Solís-Ramírez, M.J. 1967. Aspectos biológicos del pulpo Octopus maya Voss y Solís. Public. Inst. Nal. Inv. Biol. Pesq. México. 18: 1-90.

Solís-Ramírez, M.J. 1988. El recurso pulpo del Golfo de México y del Caribe Mexicano. p. 463-478. In SEPESCA (ed.) Los recursos pesqueros del país. XXV Aniversario del INP. México.

Solís-Ramírez, M.J. 1990. The Octopus maya Fishery of the Yucatan Peninsula. p. 1-9. In Lang, Hochberg \& Ambrose (Eds.) : The fishery and market potential of Octopus in California. CMSC. San Francisco, California.

Solís-Ramírez, M.J. 1994. Mollusca de la Peninsula de Yucatán, México. p. 13-32. In A.Yañez-Arancibia (ed.). Recursos Faunísticos del Litoral de la Península de Yucatán. Univ. Autón. Campeche. EPOMEX. Serie Científica, 2. Campeche, México.

Solís-Ramírez, M.J. y E.A. Chávez. 1986. Evaluación y régimen óptimo de pesca del pulpo de la Península de Yucatán. Anal. Inst.Cienc. Mar. y Limnol. UNAM, México, 13: 1-18.

Solís-Ramírez, M.J., M.E. González de la Rosa \& J.A. Sánchez. 1991. Coeficientes de la relación pesolongitud y parámetros de crecimiento del pulpo Octopus maya (Mollusca: Cephalopoda) de la costa de Yucatán. Temporada 1988. XI Congreso Nacional de Zoología. Mérida Yucatán, México.(Res.).

Solís-Ramírez, M.J., F. Arreguín-Sánchez \& J.C. Seijo. 1999. Pesquerías de cefalópodos. In FloresHernández, D., P. Sánchez-Gil, J.C. Seijo \& F. Arreguín-Sánchez (eds.). Análisis y diagnóstico de los recursos pesqueros críticos del Golfo de México. Univ. Autón. Campeche, EPOMEX Serie Científica 7. Campeche, México. (in press)

Thompson, W.E. \& F.H. Bell. 1934. Biological statistics of the Pacific Halibut. 2. Effect of the changes in fishing intensity upon total yield and yield per unit of gear. Rep.Int Fish. Pacif. Halibut Comm 8: 1-49.

Wetherall, J.A. 1986. A new method for estimating growth and mortality parameters from length frecuency data. Fishbyte 4: 12-14. 